\title{
Missing dinosaur skulls raise new fears of smuggling in Moscow
}

Munich. Palaeontologists are growing increasingly concerned about the disappearance of at least five valuable dinosaur skulls and other fossils from the Museum of the Palaeontological Institute in Moscow.

Scientists are worried that the skulls may have been smuggled abroad and sold on the black market. But the reluctance of senior officials to discuss the disappearances even with the police - appears to be frustrating attempts to solve the problem. The institute, part of the Russian Academy of Sciences, houses one of the world's most important fossil collections.

Following publicity over a wave of thefts in 1992, officials from the institute agreed to participate in an international working group set up in 1994 to help locate and return stolen Russian fossils (see Nature 371, $729 ; 1994)$. The group is led by David Unwin, of Bristol University's Department of Geology, and Michael Shiskin, of the Palaeontological Institute in Moscow.

The officials also agreed to improve security at the institute to prevent further disappearances, and to terminate all contact with commercial organizations selling fossils. Smaller invertebrate and vertebrate fossils have nevertheless regularly continued to disappear - to the frustration of scientists at the institute, who have been told not to speak publicly about any disappearances they notice.

The recent vertebrate disappearances have only increased concern. They include skulls of two Protoceratops and a Breviceratops kozlowskii, and the upper and lower jaw of the species Tarbosaurus efremovi, both jaws being more than half a metre long. The five fossils disappeared from locked basement stores sometime before August, when the absence was discovered.

The Tarbosaurus lower jaw is a particularly significant loss to science. It is the world's principal reference specimen, and is central to attempts to answer fundamental questions about the dinosaur, such as whether it is the same species as Tyrannosaurus rex.

The value of these five dinosaur fossils is estimated to be around US\$11,000. Although the apparent theft of at least one collection of invertebrate fossils has been reported to the police, the more serious disappearance of these vertebrate fossils has not - to the distress of institute scientists.

Alexei Rozanov, the director of the institute, declines to comment on the apparent reluctance to report the disappearances. But Igor Novikov, his deputy director, justi- fies it on the grounds that "we cannot expect much help in such cases from the police, either Russian or Interpol”.

Nevertheless, after an enquiry last month from the western members of the international working group for the return of stolen

\section{IMAGE UNAVAILABLE FOR COPYRIGHT REASONS}

Missing link: skull of Tarbosaurus efremovi, part of which has recently disappeared from storage.

Russian fossils, and apparently concerned by rumours of the theft, Novikov confirmed the loss of the five dinosaur fossils, and provided descriptions and internal catalogue numbers. But, despite repeated requests from the working group, Novikov has not provided illustrations needed for an international search for the fossils.

Novikov did not confirm the disappearance of historically important mammoth tusks and a large number of ammonites, which some scientists say are missing.

The international working group is planning to publish details of the dinosaur fossils in palaeontological journals, as well as on the Internet, in the hope that they may be located and returned. The prospects are not good; only one of about 50 fossils stolen two years ago has so far been returned.

Since the fall of Communism, the Palaeontological Institute, like all publicly funded research institutes in Russia, has been in severe financial difficulties and has had to find new ways to raise money. In the early 1990s, staff members set up businesses for the sale of fossils using the institute's address. But this practice has now been stopped, says Novikov.

Stolen fossils could be leaving the country illegally through St Petersburg port or Moscow airport. In theory they could also be smuggled out of the institute in crates used to send specimens to exhibitions abroad.

The institute raises about US $\$ 30,000$ a month by mounting exhibitions around the world. Some personnel are allowed to accompany the exhibitions and receive a generous daily allowance in foreign currency, as well as the opportunity to visit foreign palaeontological museums and institutes. These inducements, as well as the fear of losing their jobs, is said to have encouraged staff to say nothing about missing fossils. But it has led to discontent among some of these scientists within the institute.

Novikov, speaking for the institute, says that its directors are cooperating with various state bodies, including customs, "to put the fossil trade under the control of experts". He says that stronger locks have been put on laboratory doors, and access to material has been restricted.

$\mathrm{He}$ argues that the concerns of western scientists reflect prejudice against their colleagues from former Communist countries, and suggests that they should focus less on his institute and more on the burgeoning black market in fossils in the West, which drives demand for stolen material.

Novikov also accuses some westerners of exploiting the institute's collection. He says Bernard Bredow, owner of a small museum in Bavaria called Mammutheum, kept material well beyond an agreed loan period, and made casts of fossils without permission.

Bredow replies that delays in returning some specimens used in an Austrian exhibition were caused by problems at customs in Austria and Moscow. He says that he signed a legal agreement in 1991 with the institute's former director, Leonid Tatarinov, giving him full responsibility for the institute's activities in Germany and the right to make casts of fossils.

"This contract is still valid," says Bredow. But he says he has avoided contact with the institute since 1992, after concern about dealers to whom he had been introduced by the institute, and who snatched fossils that he had originally bought from them while he on display at a trade fair in Munich.

Bredow says that the argument with the dealers arose because he had not paid all of the three separate bills he received for the same items. Police were called in, and the fossils - which were not part of the museum's collection - were retrieved.

He says that he is keen to help the institute, but that this had become impossible because of a lack of "transparency" that made it difficult to know what was going on. But Bredow says that he will do what he can to help locate the missing fossils.

Alison Abbott 